\section{Tourist's rational and emotional engagement across events: a multi-event integration view}

Tourist's rational and emotional engagement

José A. Folgado-Fernández

Department of Financial Economics and Accounting, University of Extremadura, Cáceres, Spain

Paulo Duarte

Department of Management and Economics, University of Beira Interior, Covilhã, Portugal, and

\author{
José Manuel Hernández-Mogollón \\ Department of Business Management and Sociology, \\ University of Extremadura, Cáceres, Spain
}

2371

Received 27 September 2020

Revised 15 December 2020

27 February 2021

10 March 2021

Accepted 10 March 2021

\begin{abstract}
Purpose - The purpose of this study is to investigate and compare the role of communication, structural and intangible elements on both tourists' rational and emotional engagement across five different types of events (nature, gastronomy, religion, theatre and music).

Design/methodology/approach - Responses from 1,528 tourists were obtained through a face to face questionnaire in five heterogeneous events in the Spanish region of Extremadura, a well-known cultural tourism destination. Linear regressions were used to evaluate focal constructs' contribution (emotional and rational engagement, formal and informal communication and structural and non-structural elements) on tourists' engagement across events.

Findings - The results revealed that tourist's rational and emotional engagement depends on the type of event. Non-structural elements seem to be important for rational and emotional engagement for gastronomic and cultural events. Besides the impact of structural elements on rational engagement, all other factors seem to have a mixed influence. Therefore, practitioners must select the factors to highlight according to the type of events, besides structural factors.
\end{abstract}

(C) José A. Folgado-Fernández, Paulo Duarte and José Manuel Hernández-Mogollón. Published by Emerald Publishing Limited. This article is published under the Creative Commons Attribution (CC BY 4.0) license. Anyone may reproduce, distribute, translate and create derivative works of this article (for both commercial and non-commercial purposes), subject to full attribution to the original publication and authors. The full terms of this license may be seen at http://creativecommons.org/ licences/by/4.0/legalcode

Project co-funded by FEDER and Junta de Extremadura (Spain) (Reference No. GR18109).

\section{JUNTA DE EXTREMADURA}

Fondo Europeo de Desarrollo Regional

Una manera de hacer Europa

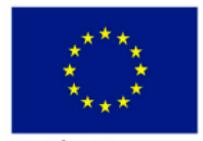

Unión Europea 
$\mathrm{IJCHM}$ 33,7

Practical implications - The current results allow tourism managers to understand the mechanisms for tourists' engagement in a multi-event scenario to strategically select and use and communicate each type of appeal when planning and communicating events to specific target audiences.

Originality/value - Unlike most studies that focus on a single event or typology, this study combines a set of heterogeneous events to provide a complete picture of tourism engagement for the tourism sector.

Keywords Tourism management, Emotional engagement, Destination communication, Events tourism, Rational engagement

Paper type Research paper

\section{Introduction}

Tourism based on events' celebration seeks to create and develop events to attract tourists, promote places and nurture emotional and rational engagement. Thus, it is expected that the event can be positively related to the territory where it is held (Getz and Page, 2016). Tourism events based on local culture, traditions and resources have an additional appeal and value because of their authenticity, as they can provide attendees with a unique and memorable experience (Jiang and Chen, 2019). Events have become an efficient instrument in promotional campaigns of destination tourism (Brennan-Horley et al., 2007). Its value is even more relevant in small towns, where events and festivals often significantly contribute to the economic development and infrastructure improvement (Gibson and Connell, 2016), to increase business activity (Pickernell et al., 2007) and to encourage greater participation and involvement of residents (Wilks and Quinn, 2016).

Compared to mega-events that need attendance and support from large companies and state funding (Jiang and Chen, 2019), tourism grounded on genuine events linked to the territory can help preserve and emphasise local characteristics while promoting tourism progress (Ezeuduji, 2015). Cultural resources and local traditions contribute to strengthening the destination's image and promoting it to attract new tourists (Lee and Bai, 2016). The rapid growth of events planned by local administrations and regional governments reveals the need to thoroughly examine the elements they are based on to provide indications for future research and support both academics and professionals (Getz and Page, 2016).

The relationship between destination communication, emotional engagement and rational engagement is widely reported in tourism literature as central components of effective tourism event management (Afshardoost and Eshaghi, 2020; Buhalis, 2019; Murphy et al., 2007; Wu and Liang, 2020). Therefore, the current study aims at assessing the strengths of the different sources of information (intentional or informal), the structural or permanent elements at the destination, and the immaterial resources associated with the destination heritage, to predict the rational and emotional engagement of tourists. While the majority of studies address event tourism economic impact (Lu et al., 2020), the originality and value of the current study lie on the set of factors being evaluated, the focal dependent variables but also on the fact that uses a multi-event approach that reinforces the validity of the results.

Although the literature includes different contributions that compare events, studies comparing the same set of variables across several events with different characteristics targeted at predicting tourist engagement are scarce. Thus, this paper makes a significant contribution to the body of knowledge by exploring visitors' rational and emotional engagement across five different types of events (nature, gastronomy, religion, theatre and music) organised annually in the Spanish region of Extremadura, a recognised inland destination for its history, nature and gastronomy and its cultural resources. Theoretically, the study of these two factors is important because they strongly influence the event tourists' future attitude and behaviour. The results provide tourism researchers with useful information 
to improve and measure the experiences of event tourists. From a managerial point of view, the current study is relevant because it illustrates how the local economy can benefit from eventbased tourism and guide the design of events to obtain superior economic results.

\section{Theoretical background and hypotheses development}

\subsection{Emotional and rational engagement}

In the process of choosing a destination, tourists value different alternatives because they are influenced by both emotional and psychological factors (attitudes, feelings, values, or personal characteristics) as well as by objective and rational attributes (design, physical attractions, price or advertising) (García-Milon et al., 2020). The emotional component is composed of feelings, motivations and experiences about a destination (Beerli and Martín, 2004; Rodríguez Del Bosque and San Martín, 2008). These feelings influence the memories of tourists' experience and contribute to the future commitment to the destination (Afshardoost and Eshaghi, 2020) by reliving the event through shared images and comments with friends and family (Tung and Ritchie, 2011). Thus, the emotional engagement has a personal and unique meaning for each person linked to the tourist's experience in a specific place and moment (Shamsuddin and Ujang, 2008). In the case of events, this issue is especially relevant because the experience is the event, especially if the events offer additional activities such as tastings, experiential guided tours, thematic classes and workshops (Wu and Liang, 2020). After the event, participants can reflect on what they have learned and discuss this with other participants or express their experiences during the event (Ok et al., 2020).

On the other hand, rational engagement refers to experiences related to consciousness, memory, learning, or reasoned understanding of the experience lived by the tourist (Atadil et al., 2018). From this perspective, a tourist destination is valued by the tourist-based on a group of attributes that correspond to the resources that a certain place possesses (Stylidis et al., 2017). Thus, rational engagement grounds on beliefs and knowledge about a destination, focussing mainly on functional or tangible physical attributes but also taking into account its history, nature or culture among other variables (Baloglu and McCleary, 1999; Pike and Ryan, 2004; Gallarza et al., 2002).

Therefore, engagement with the destination is shaped by a combination of knowledge, impressions, perceptions, prejudices and thoughts about the place (Jenkins, 1999). Given the tourist destination's emotional-rational coexistence with the tourist destination, both concepts are considered fundamental to understand the engagement with the destination from an emotional perspective (Pike and Ryan, 2004) and a rational perspective (Baloglu and McCleary, 1999).

\subsection{Structural elements}

Structural elements are the permanent resources of a place or tourism destination, such as architectural monuments, infrastructures, unique landscapes or socio-economic environment (Baloglu and McCleary, 1999). Tourists, frequently travel to a destination knowing that what they are going to find and with their mindset in enjoying the comfort and pleasantness provided by the elements available at the destination (Del Bosque and San Martín, 2008). These elements, along with other attributes, but mostly the tourist's experience with them, contribute to the formation of engagement with the place (Lew, 1987).

Tyrrell and Johnston (2001) indicate that for a remarkable experience to develop it requires the interaction of natural and cultural resources, infrastructure and services and not only the effects resulting from the events. The presence of the structural elements is crucial to the development of tourists' rational engagement (Uriarte et al., 2019), as visitors are

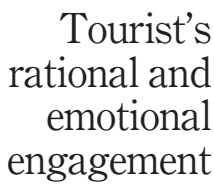

2373 
IJCHM

33,7

\section{4}

certain that when travelling to a destination to attend an event they feel secure of being able to enjoy the experience with the event but also with other permanent attractions of the destination (Chi and $\mathrm{Qu}, 2008)$. Typically, they are interpersonal, sensory and physical attributes that the tourist expects to find in the destination and that adds value to it during the experience (Hosany and Gilbert, 2010).

Several studies highlight that the tourist's complete experience is formed through the interaction of several elements (Mossberg, 2007; Chi et al., 2020). The well-balanced integration of structural elements and events can induce both thoughts and feelings and significantly influence rational and emotional engagement. Accordingly, the following hypotheses are proposed:

H1a. Structural elements can induce a favourable rational engagement.

$H 1 b$. Structural elements can induce a favourable emotional engagement

\subsection{Tourism events}

Tourism events are specific celebrations planned and organised by local administration or private organisations around a specific theme at a location or a tourism destination, and it may include several activities. Usually, the events' content is associated with specific natural attractions and other tourism resources such as traditions, heritage and values of the place where it is held. Tourism events are increasingly relevant to attract tourists to the destination because they represent an opportunity to promote and develop the local economy (Gibson and Connell, 2016). Event-based tourism is particularly important in small cities that intend to promote their territory, particularly in destinations lacking imposing monuments or outstanding natural resources and where it is more difficult to count on the positive effects of mega-events (Gibson and Davidson, 2004).

Some studies hold that small events can provide more added value for the tourist itself and the destination's economic and social development than mega-events (Lima et al., 2016). These smaller-size recurring events are considered increasingly important, especially those based on local culture and traditions, as they enhance rational and emotional engagement, as opposed to mega-events whose effects quickly fade out after the event ends (Park and Park, 2017; Laing, 2018).

Devesa et al. (2010) sustain that attending tourism events influences tourists' perception towards the destination, namely, by eliciting rational engagement. Likewise, tourism events also promote emotional engagement if the tourist is provided with the opportunity to go from being a passive observer to an active participant and moulding its own unique experience (Vivek et al., 2012). Therefore, events have an important role as enhancers of the emotional engagement towards the place where they occur, as they serve as positive catalysts of the tourist's emotional part (Getz and Page, 2016).

Accordingly, $H 2 a$ and $H 2 b$ are proposed, suggesting that the celebration of tourism events can positively influence both rational and emotional engagement:

$H 2 a$. Tourism events induce a favourable rational engagement with the destination.

$H 2 b$. Tourism events induce a favourable emotional engagement with the destination.

\subsection{Communication}

The communication of a place or tourism destination is considered by many as one of the main antecedents contributing to the formation of the destination's engagement 
(Murphy et al., 2007). Communication is also pointed out as an important for destination marketing organisations (DMOs) and policymakers (Almeida-Santana and Moreno-Gil, 2017), for the creation of positive expectations and quality experiences capable of promoting the tourist's rational and emotional engagement (Zeithaml et al., 1996).

Gunn's (1988) communication model suggests the existence of two types of tourism communication that influence the tourist's image of the destination and consequently the tourist engagement: organic communication and induced communication. The first is based on unintentional testimonies such as family and friends' recommendations and news and information spread in traditional media and through social media platforms. On the other hand, induced communication, or intentional communication, refers to commercial tourism information sponsored by DMOs and distributed through official tourist guides, special publications and tourism professionals.

The continuous development of information and communication technology (ICT) has highlighted the importance of new communication sources for the tourism industry (Buhalis and Law, 2008) inducing a shift in the way the tourism sector communicates (Buhalis, 2019). Institutional digital spaces such as social networks, blogs and websites form an important source for information search when organising a trip and (Dedeoglu, 2019) to ensure a positive rational and emotional engagement with the destination (Wong et al., 2019). Additionally, in an informal way, tourists share information through their personal space in social networks and public and private groups (Ziakas and Getz, 2020), such as opinion websites where they can convey judgement on tourism experiences, which are increasingly valuable and used by other travellers (Xiang and Gretzel, 2010). The influence of online ratings on purchasing decisions is a key issue in multiple sectors, including tourism (Buhalis, 2019).

Informal communication between tourists based on the ICTs is positively related to rational and emotional engagement (Vivek et al., 2012). Thus, the evolution of ICTs imposes changes in the way DMOs approach communication with tourists (Gursoy et al., 2017), by offering new alternatives to interact with them and adding value to the experience (Kim et al., 2020). Lin and Huang (2009) provide empirical evidence regarding the influence of digital communication on tourists' experience, as it indicates a significant and positive relationship between communication and engagement. Accordingly, the following hypotheses are proposed:

$H 3 a$. Intentional communication induces a favourable rational engagement.

$H 3 b$. Intentional communication induces a favourable emotional engagement.

$H 4 a$. Unintentional communication induces a favourable rational engagement.

$H 4 b$. Unintentional communication induces a favourable emotional engagement.

Based on the proposed hypotheses (Thomas et al., 2011), Figure 1 depicts the conceptual model being assessed in the current investigation.

\section{Method}

\subsection{Sample and data collection}

The collection of information on primary data was carried out through a structured questionnaire, completed as a personal interview with each tourist with a trained interviewer's help. The questionnaire contained structured quantitative questions that took about 8-10 min to answer, with the interviewers providing a read-out of the questions and a series of indications on the nature of the work. The questionnaire was provided in Spanish.
Tourist's rational and emotional engagement

2375 


\section{IJCHM \\ 33,7}

\section{6}

Figure 1. Proposed model

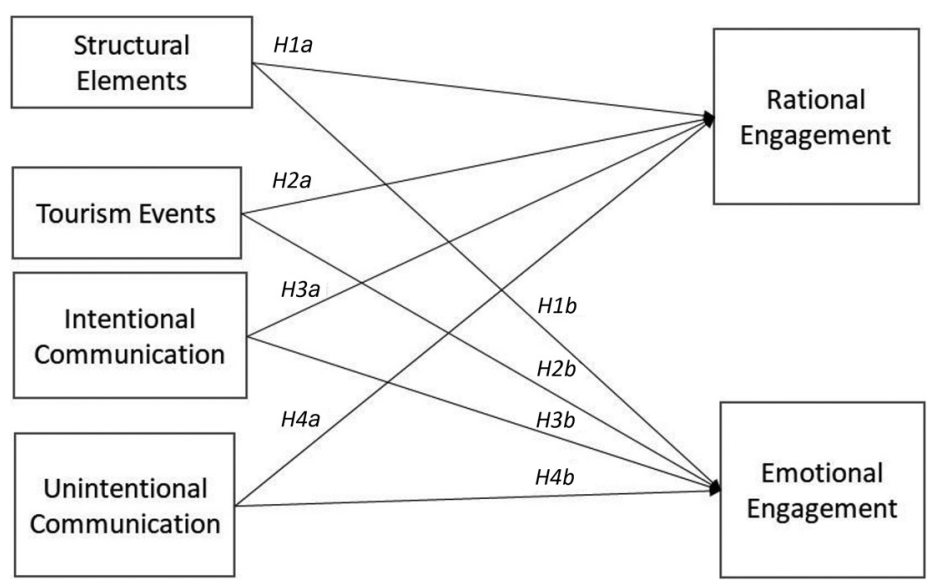

The data collection was conducted between March and August 2019. Interviews were conducted in the busiest areas of the five selected events. The five events had a sample proportional to the total number of questionnaires obtained. The data obtained from the questionnaire were analysed at an earlier stage to detect missing values and to refine the information. Forty-two responses contained missing values in a large number of indicators, a negligible number explained by the warning and consistency of the enumerators in completing the questionnaire. Given that the total number of responses was high (1.570), those with missing values were eliminated, thus considering a total of 1.528 valid responses.

\subsection{Measurements and scales}

The scales used to measure the different variables had been used and tested in several previous studies. However, sometimes these were adapted so that the questions were understood in the context of the sample.

The rational engagement was measured using nine items from the scales proposed by Echtner and Ritchie (1993) later used by Gallarza et al. (2002), Chi and Qu (2008) and Boo et al. (2009). For the measurement of emotional engagement was using four items from the base scale by Russell et al. (1981), with the developments by Beerli and Martín (2004), Pike and Ryan (2004), Del Bosque and San Martín (2008), Chi and Qu (2008) and Boo et al. (2009) was used.

Scales tested in previous studies such as those of Echtner and Ritchie (1993), Gallarza et al. (2002), Chi and Qu (2008) and Boo et al. (2009) were used to measure the perceived value of the structural or permanent elements of the destination, using eight items. To measure the effect of holding the event, eight indicators generally accepted by the literature were used, such as those of Ritchie and Smith, 1991 and Ekinci and Riley, 2001.

Intentional communication was measured using four items the Horng and Tsai (2010) and Mercille (2005) scales. The scales of Gitelson and Crompton (1983), Gruen et al. (2006) and Buhalis and Law (2008) were chosen to assess unintentional communication, using four items.

\subsection{Study setting}

The empirical research was carried out in the cities of Cáceres, Mérida, Trujillo and Plasencia along with the territory of Valle del Jerte belonging to the Extremadura region 
located in the southwest of Spain. The four host cities share a great heritage (focussing on nature, landscape, culture and gastronomy), as well as a recognised prestige as representative tourist areas of cultural tourism in Spain.

Cáceres is a city with a strong university character and has more than 3,000 hotel beds. The old part of the city was declared a World Heritage Site by UNESCO in 1986, as one of the most complete urban complexes of the Middle Ages and Renaissance in the world.

Easter Week in Cáceres is a Festival of International Tourist Interest and commemorates the passion, death and resurrection of Jesus of Nazareth through processions that take place mainly in the Monumental City. Its origins date back to the 15th century, although there are references that as early as the 13 th century there were parades in which the penitents carried torches. The WOMAD festival has been held in Cáceres since 1992. Created by the musician Peter Gabriel, WOMAD is a brand of international travelling festival based on a multicultural creative space with music from all over the world. The first festival of its kind took place in 1982 in the UK, and since then, the format has spread to other countries such as Sri Lanka, Abu Dhabi, New Zealand and Spain.

Mérida is the capital of the region of Extremadura and the seat of its government institutions. Also, it is a tourist reference throughout the world because of its important archaeological and monumental site, which was declared a World Heritage Site by UNESCO in 1993. The Mérida Festival is a prestigious classical theatre event held in the incomparable setting of the Roman Theatre, considered to be one of the buildings in the world that best represents the Roman architecture of the time of Emperor Augustus. It is the oldest classical theatre festival held in Spain and is considered to be the most important of its kind. Sixty-five editions of the festival have been held from 1933 to 2019, attracting thousands of spectators.

Plasencia is considered the capital of the Jerte Valley and is a top tourist destination owing to the monumental and historical character of the city, as well as its proximity to the tourist resources of the Jerte Valley region. This is the site of the Cherry Blossom Festival, when the cherry trees cover the whole valley with their white blossoms, creating a unique landscape.

Finally, the town of Trujillo is located in the southeast of the province of Cáceres. The historical relevance has made Trujillo an important tourist centre famous for its monuments. It was the birthplace of Francisco Pizarro, conqueror of Peru, whose equestrian sculpture, a representative icon of this town, stands in its Plaza Mayor.

The five events analysed are annual and are organised by the respective town councils in collaboration with, among others, the regional government of Extremadura

Table 1 summarises the characteristics of the events analysed.

\begin{tabular}{llllr}
\hline Event & City & Date & Type of event & Participants \\
\hline Easter week & Cáceres & March & Cultural/Religious & 54.000 \\
Womad Festival & Cáceres & May & Music & 100.000 \\
Cherry blossom & Plasencia y Valle del Jerte & April & Natural & 80.000 \\
Cheese fair & Trujillo & May & Gastronomic & 150.000 \\
Theatre Festival & Mérida & July-August & Cultural & 75.000
\end{tabular}

Source: Own made based on the following sources of data. The number of attendees in the 2019 editions provided by (1) Easter in Cáceres: Excmo. Townhall. (2) Womad Festival: Festival Management. (3) Cherry Blossom Festival in Valle del Jerte: Grouping of municipalities. (4) Trujillo National Cheese Fair: Fair Institution. (5) Mérida Classical Theatre Festival: Festival Director

Table 1. Characteristics of the events 
$\mathrm{IJCHM}$

33,7

\subsection{Data analysis}

A score was constructed for each variable (emotional engagement, rational engagement, intentional communication, unintentional communication, structural and non-structural elements). The score was calculated based on the average of the items in each construct. Then, linear regressions were performed using separately, emotional engagement and rational engagement as dependent variables and the remaining as independent variables. Normality of the data was evaluated based on skewness and kurtosis, which present values between -0.002 and 0.483. Multicollinearity was assessed using the variance inflation factor (VIF). The results indicate no multicollinearity problems in the data, as all the calculated values are inferior to the most conservative threshold of 3 . SPSS version 27.0 was used to perform data analysis.

\section{Results}

The sociodemographic data on people attending the five events were analysed and reported in Table 2, indicating that respondents' characteristics do not differ much among the samples. All five samples are mainly composed of Spanish tourists $(\geq 98 \%)$, mainly women $(\geq 54 \%)$, and the majority holding a college degree $(\geq 57 \%)$. Regarding age, there are significant differences. The major group is between 45 and 64 years old, except for the Womad Festival. Because of its peculiar characteristics, more than half of the participants aged under 26. Probably owing to the type of event, $71 \%$ of the respondents at the Mérida Theatre Festival aged 45 years old or more. The expressed loyalty of those attending the events is around $50 \%$ for tourists who had visited the region more than three times. In the case of the theatre festival, this percentage is even higher, reaching $67 \%$.

These results are globally in agreement with the works by Wong et al. (2019), Gibson et al. (2012) or Matheson (2008), except for age in the case of the Womad Festival where there are substantial differences. The difference may result from the types of music-focussed by Womad, particularly targeted at the younger market, and the large number of college students living in Cáceres and enrolled in the University of Extremadura.

As for the descriptive analysis of the sample, Table 3 presents the items used with their mean values and standard deviations for all variables in the five scenarios. The analysis yielded mean values between the maximum recorded for an affective engagement at the classical theatre festival (mean $=4.5172$ ) and the minimum for intentional communication at the Womad festival (mean = 2.185). As for the standard deviation, for the five samples, there are small values, which in almost all cases do not exceed unity, thus indicating a high concentration of the data obtained.

To evaluate the influence of the factors depicted in the conceptual model, a score was computed for each factor and event by averaging the items within the scale. The score was used to test the effect of the factor on tourists' engagement. Multiple regression was conducted to evaluate if intentional and non-intentional communication, structural elements and events' characteristics predicted the tourists' rational and emotional engagement for each event.

Table 4 presents the model summary for each of the linear regressions. The $R$-square results indicate that rational engagement is better explained by the factors under analysis than emotional engagement. The only non-significant regression equation is for rational engagement in the case of the Mérida's Theatre event $(\mathrm{F}(4,300)=0.391, p=0.815)$ with an $R^{2}$ of 0.005 .

The results show consistency for the Easter and Cheese events, as they are associated with a better prediction for both rational and emotional engagement. In the case of rational engagement, it is important to notice the similarity of the R-square between the gastronomic type events.

The structural elements seem to be determinant for the rational engagement independently from the event because all $\beta$ coefficients are significant. Communication is 


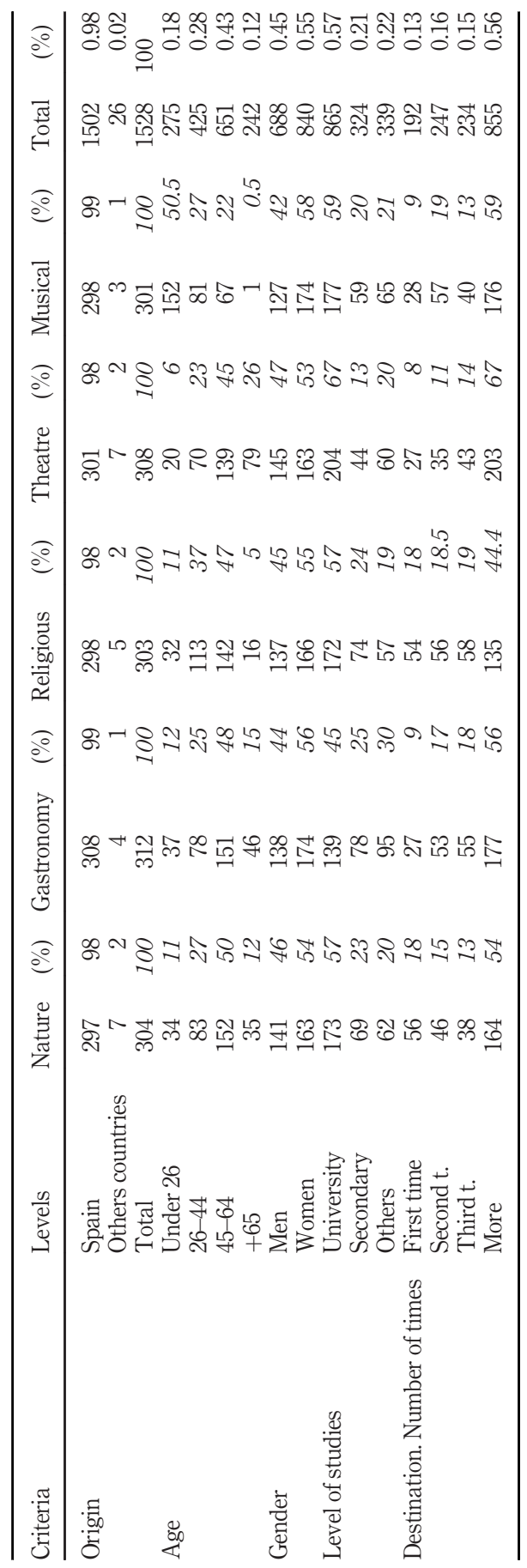

Tourist's rational and emotional engagement

2379

Table 2. Sample profile 


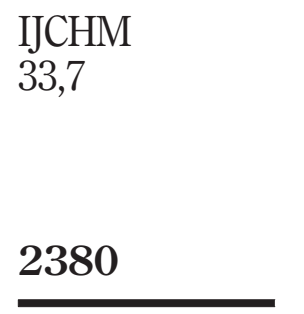

Table 3.

Descriptive statistics for indicators and composite scores

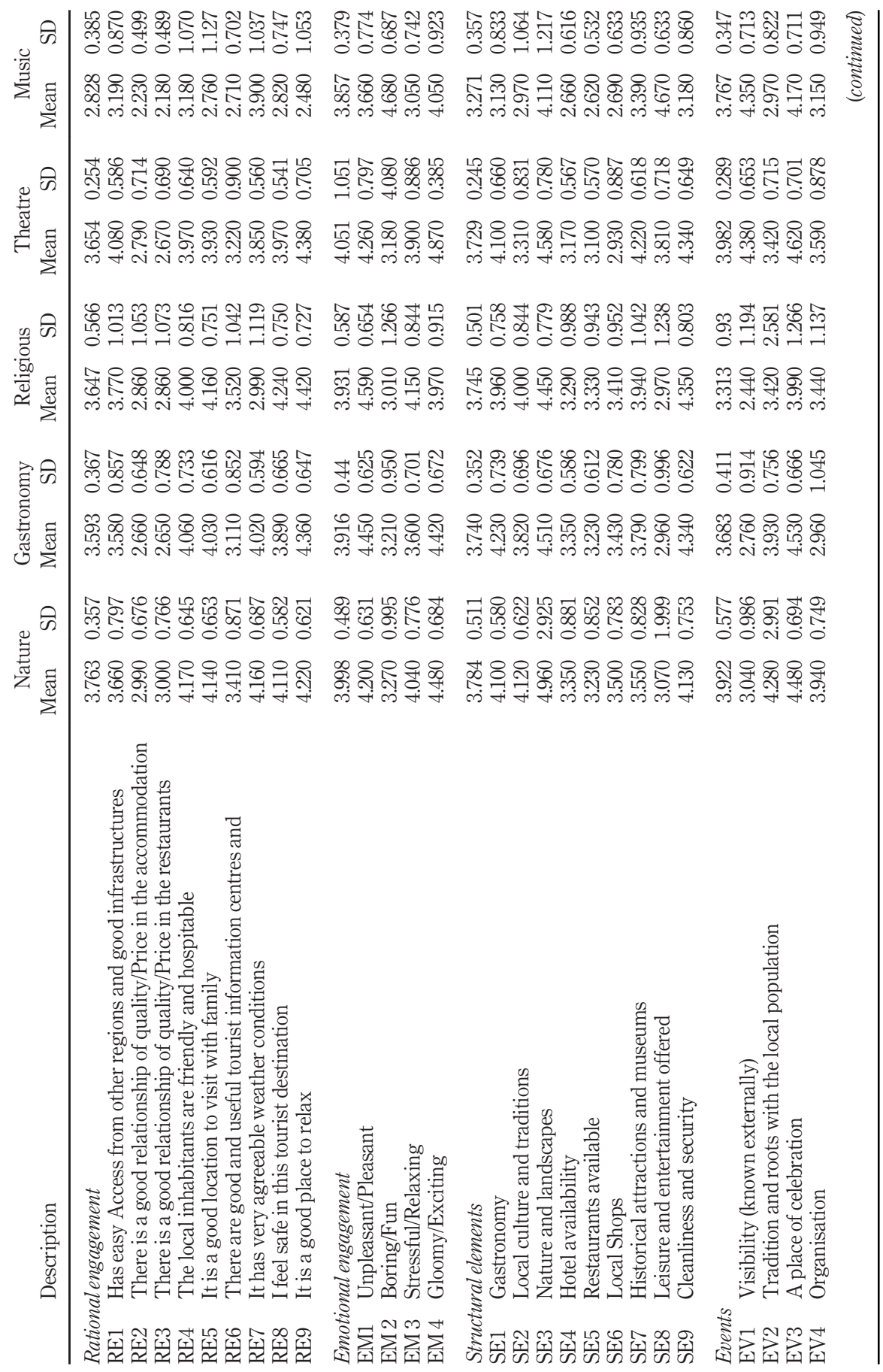




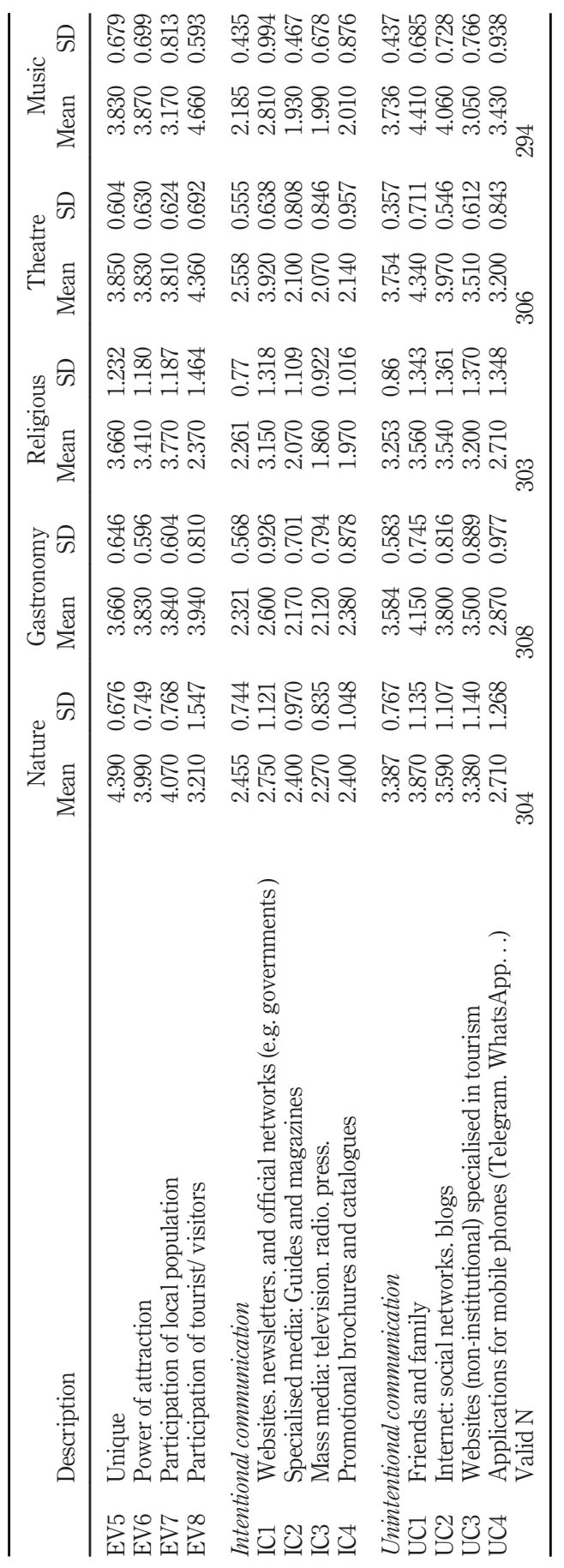

Tourist's rational and emotional engagement

2381

Table 3. 
IJCHM

33,7

\section{2}

Table 4.

Model summary for each of the linear regressions

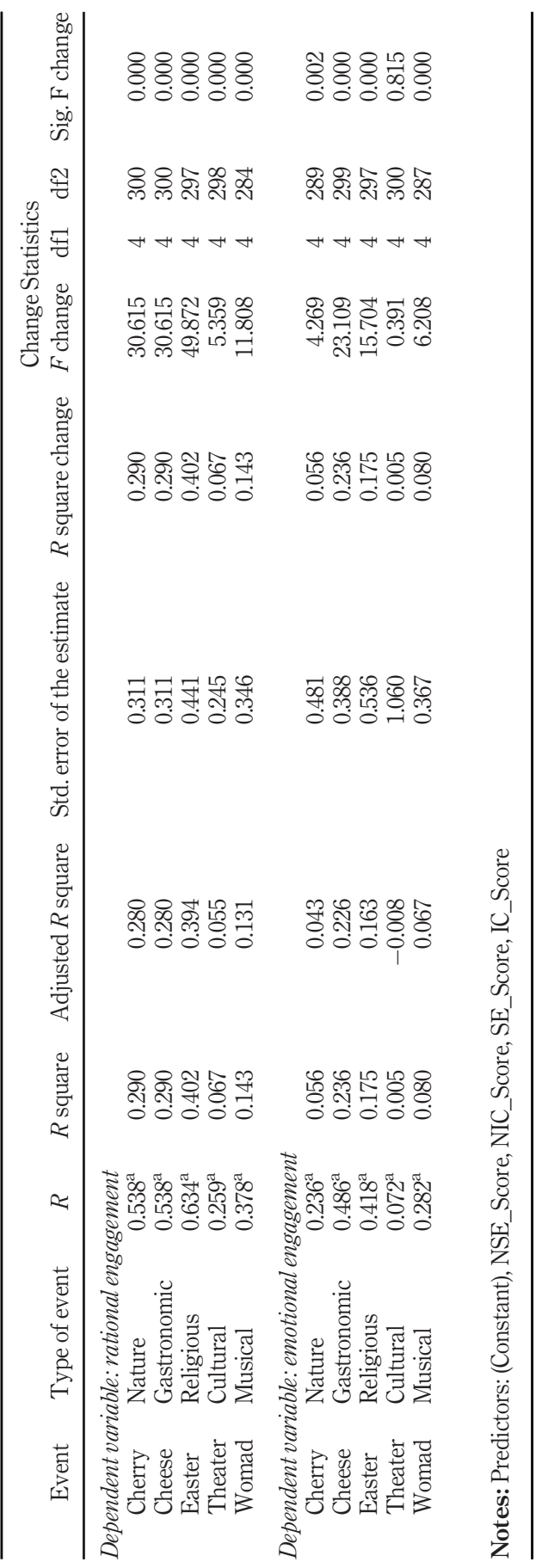


only significant for rational engagement with cherry and holy week (Easter), yet presenting a negative sign (Table 5). The emotional engagement is harder to achieve, and only the structural and non-structural elements show the ability to predict it.

According to the results in Table 5, structural elements are relevant to predict the emotional engagement with the cheese fair $(\beta=0.32, p<0.00)$, but not to the other gastronomic event, the cherry festival $(\beta=0.06, \mathrm{p}=0.264)$. The non-structural elements are significant to predict the emotional engagement with both the gastronomic events, the cherry festival $(\beta=0.21, p<0.00)$, the cheese fair $(\beta=0.26, p<0.00)$ and the Womad musical festival $(\beta=0.22, p<0.00)$. Despite the importance of communication, and contrary to our expectations, neither intentional nor informal communication seems to have a meaningful impact on engagement, particularly on emotional engagement.

Table 6 summarises the results of the hypotheses testing according to the type of event, showing that there is no general rule that applies to all types of events because only the influence of structural elements on rational engagement seems to behave identically independent of the type of event. The number of hypotheses supported with the structural elements (7) is slightly superior to the hypothesis linked to events (5), indicating that both have a significant impact on engagement in general, but the structural elements are key.

Interestingly, non-intentional or informal communication does not affect tourists' emotional engagement regardless of the type of event.

\section{Discussion and conclusions}

The findings reported in this paper are important because they were obtained from samples gathered in five different types of events, increasing the odds of being generalisable. Being grounded in five events of different types (nature, gastronomy, religion, theatre and music) and by comparing tourists' opinions and engagement, the current study stands out from the existing literature. Based on the current findings, researchers and those responsible for planning and managing the tourist destination can identify the factors that increase the degree of engagement with the destination, so they can expand the scientific research but also adopting the appropriate measures to strengthen this engagement and learn more about the tourist who is attracted to this type of events (Uriarte et al., 2019).

The results show that rational engagement is better predicted by the factors analysed than emotional engagement. Besides, the importance of given to structural or permanent elements at the destination suggested by Stylidis et al. (2017) was confirmed because they influence the rational engagement for all events. The results also reveal that tourists' rational and emotional engagement depends on the event type (Getz and Page, 2016). There is a special influence on events based on nature and music in consonance with what was suggested by Vermeir and Verbeke (2006). The explanation may lie in the higher level of active participation by visitors to these two types of events, which elicit a more intense experience and consequently a higher level of rational and emotional engagement (Kim et al., 2020).

These findings are in line with previous studies (Organ et al., 2015; Tarkiainen and Sundqvist, 2009) and make a significant contribution to the debate on the importance of the role of tourists' active participation in events to foster engagement (Ok et al., 2020).

Based on the results, it is also notorious that communication, either intentional or informal, about the destination and the event, has little or no influence on tourists' engagement. When it does, it is only the informal communication that stands out. These findings follow previous studies by Liu et al. (2019) and raise doubts about why communication is usually considered key for tourism promotion. These and similar future findings may stimulate a turn in the investment strategy for destinations, which may decide to allocate these resources to improve tourists' experience by improving structural elements

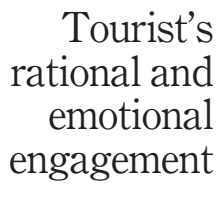

2383 
IJCHM

33,7

\section{4}

Table 5.

$\beta$ coefficients value and statistical significance

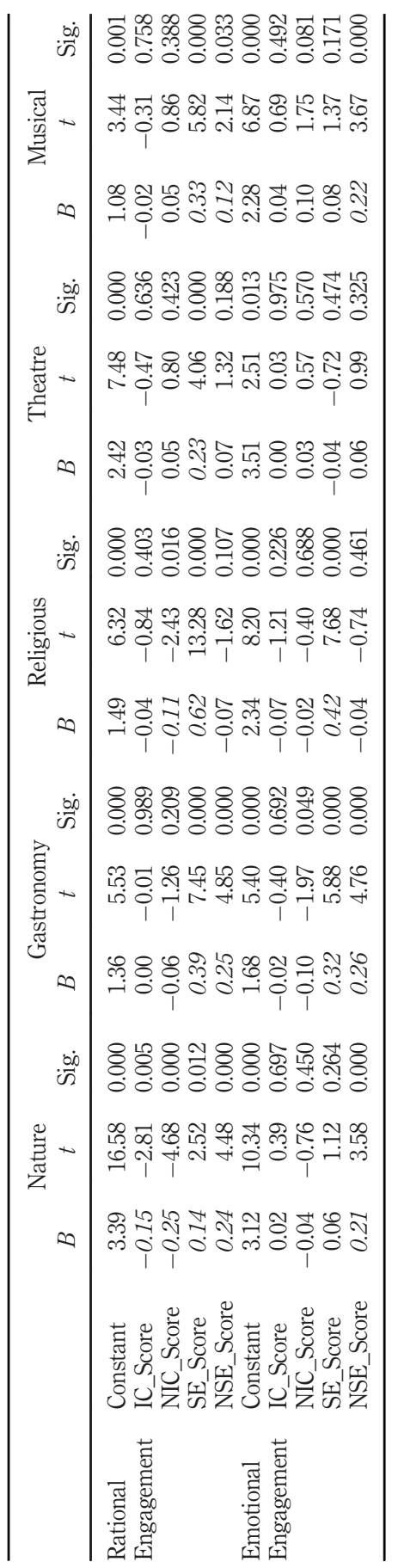


and the attractiveness of the events (Organ et al., 2015). Investing in ways of conserving the memory of the remarkable experiences associated with the event and promoting the tourist engagement through the exchange of experiences must be considered a priority (Geus et al., 2016), as these memories can induce emotional engagement and relive the special moments associated with the event (Richards, 2019).

In summary, the results indicate that holding events is a good way of attracting tourists and promoting engagement with a tourism destination. Different visitor profiles could be identified according to the type of event studied, reinforcing the understanding that no magic formula can be universally applied to all different tourism events (Gyimothy, 2009). Promoters, decision-makers, and DMOs must pay detailed attention to the coordination and harmony between structural elements and the events, improve the overall experience and achieve a higher level of both rational and emotional engagement with the destination (Lu et al., 2020). Communication must not be completely neglected in the face of the poor results in determining tourists' engagement. The consideration here is that regardless of its institutional or informal nature, informative communication can increase awareness about the destination and the events taking place there (Buhalis, 2019).

\subsection{Theoretical implications}

This study found a large and unprecedented research gap in the knowledge literature on tourism events. Previous research analysed tourism events and festivals in isolation but did not compare, during their visit to the destination, the engagement of tourists in five events of different typology. Thus, this work complements and expands the literature on event tourism on a theoretical level, exploring and comparing tourists' perceptions and engagement based on five different events (McKercher et al., 2006). The work is particularly relevant because it uses a multi-event sample to assess the role of structural elements, events and intentional and unintentional information in predicting rational and emotional engagement. This approach provides an expanded theoretical basis for other researchers to compare their findings on the same topic. Besides, this work provides a framework for the profile of tourists attending each type of event that can be used to guide future research. The segmentation and identification of groups of tourists are considered key for the design and development of different tourism marketing strategies supported by informal communication produced in social networks as opposed to formal communication (Rahman et al., 2020). In this sense, the importance of the progress of new communication channels is evident, offering advanced multimedia tools that can improve event communication (Ziakas and Getz, 2020), based for example on virtual reality or social networking sites (Gursoy et al., 2017).

\begin{tabular}{llllll}
\hline Hypothesis & Nature & Gastronomy & Religious & Theatre & Musical \\
\hline$H 1 a$ & Supported & Supported & Supported & Supported & Supported \\
$H 1 b$ & Not supported & Supported & Supported & Not supported & Not supported \\
$H 2 a$ & Supported & Supported & Not supported & Not supported & Supported \\
$H 2 b$ & Supported & Not supported & Not supported & Not supported & Supported \\
$H 3 a$ & Supported & Not supported & Not supported & Not supported & Not supported \\
$H 3 b$ & Not supported & Not supported & Not supported & Not supported & Not supported \\
$H 4 a$ & Supported & Not supported & Supported & Not supported & Not supported \\
$H 4 b$ & Not supported & Not supported & Not supported & Not supported & Not supported \\
\hline
\end{tabular}

Tourist's rational and emotional engagement

2385 
IJCHM

33,7

\subsection{Implications for management}

The combined analysis of multiple events has generated findings that have practical implications. Tourism managers have evidence that for promoting tourists' engagement, it is necessary to concentrate largely on the structural elements and congruence with the event characteristics. Furthermore, they must acknowledge that an event can become a communication tool aimed to strategically promote the destination by indorsing unique resources capable of attracting tourists and improving the territory's engagement.

The findings recommend the development of customised programs for event tourists which allow visitors to participate actively in the activities to generate more intense experiences, promote higher levels of engagement and increase memorability, for example, by designing activities aimed at encouraging tourists to experience new and pleasant sensations far outside of their usual routine. The value of these experiences must constitute a major objective for the promoters. Being successful in this task will improve the emotional engagement and support long-term relationships that will improve the destination's attractiveness and competitiveness. This approach can be particularly useful within the COVID-19 pandemic context for resuscitating tourism, which has been severely affected. Favouring the hosting of small-scale open-air events in unusual places may generate a new niche to counteract the negative social and economic impacts caused by the pandemic (Hall et al., 2020).

\subsection{Limitations and future research}

Like any research, the current one as limitations that must be acknowledged. Despite the advantage of analysing five events, these were held in a single Spanish region, and the participants were interviewed during the attendance to the event. Conducting a post-event survey may have helped get a longitudinal measure for the engagement level to evaluate the persistence of the engagement over time. Future studies can expand the current study by deepening the previous idea and by including loyalty or engagement of destiny in the model. It would also be interesting to investigate ways of turning communication effective for increasing tourists' engagement with a destination. A final note to the sample is composed almost completely by Spanish tourist; therefore, it seems reasonable to assume that the conclusions apply more to the context where domestic tourists attend events, regardless of the country or region.

\section{References}

Afshardoost, M. and Eshaghi, M.S. (2020), "Destination image and tourist behavioural intentions: a Meta-analysis", Tourism Management, Vol. 81, pp. 104-154.

Almeida-Santana, A. and Moreno-Gil, S. (2017), "New trends in information search and their influence on destination loyalty: digital destinations and relationship marketing", Journal of Destination Marketing and Management, Vol. 6 No. 2, pp. 150-161.

Atadil, H.A., Sirakaya-Turk, E., Meng, F. and Decrop, A. (2018), "Exploring travelers' decision-making styles", International Journal of Contemporary Hospitality Management, Vol. 30 No. 1, pp. 618-636, doi: 10.1108/IJCHM-11-2016-0613.

Baloglu, S. and McCleary, K.W. (1999), "A model of destination image formation”, Annals of Tourism Research, Vol. 26 No. 4, pp. 868-897.

Beerli, A. and Martín, J.D. (2004), “Tourists' characteristics and the perceived image of tourist destinations: a quantitative analysis-a case study of lanzarote, Spain", Tourism Management, Vol. 25 No. 5, pp. 623-636.

Boo, S., Busser, J. and Baloglu, S. (2009), “A model of customer-based brand equity and its application to multiple destinations", Tourism Management, Vol. 30 No. 2, pp. 219-231. 
Brennan-Horley, C., Connell, J. and Gibson, C. (2007), "The parkes elvis revival festival: economic development and contested place identities in rural Australia”, Geographical Research, Vol. 45 No. 1, pp. 71-84.

Buhalis, D. (2019), "Technology in tourism-from information communication technologies to eTourism and smart tourism towards ambient intelligence tourism: a perspective article", Tourism Review, Vol. 75 No. 1, pp. 267-272, doi: 10.1108/TR-06-2019-0258.

Buhalis, D. and Law, R. (2008), "Progress in information technology and tourism management: 20 years on and 10 years after the Internet-The state of eTourism research", Tourism Management, Vol. 29 No. 4, pp. 609-623.

Chi, H.K., Huang, K.C. and Nguyen, H.M. (2020), "Elements of destination brand equity and destination familiarity regarding travel intention", Journal of Retailing and Consumer Services, Vol. 52.

Chi, C.G.Q. and Qu, H. (2008), "Examining the structural relationships of destination image, tourist satisfaction and destination loyalty: an integrated approach", Tourism Management, Vol. 29 No. 4, pp. 624-636.

Dedeoglu, B.B. (2019), "Are information quality and source credibility really important for shared content on social media?", International Journal of Contemporary Hospitality Management, Vol. 31 No. 1, pp. 513-534.

Del Bosque, I.R. and San Martín, H. (2008), "Tourist satisfaction a cognitive-affective model”, Annals of Tourism Research, Vol. 35 No. 2, pp. 551-573.

Devesa, M., Laguna, M. and Palacios, A. (2010), “The role of motivation in visitor satisfaction: empirical evidence in rural tourism”, Tourism Management, Vol. 31 No. 4, pp. 547-552.

Echtner, C. and Ritchie, B. (1993), "The measurement of destination image: an empirical assessment", Journal of Travel Research, Vol. 31 No. 4, pp. 3-13.

Ekinci, Y. and Riley, M. (2001), "Validating quality dimensions", Annals of Tourism Research, Vol. 28 No. 1, pp. 202-223.

Ezeuduji, I.O. (2015), "Strategic event-based rural tourism development for Sub-Saharan Africa", Current Issues in Tourism, Vol. 18 No. 3, pp. 212-228.

Gallarza, M.G., Saura, I.G. and García, H.C. (2002), "Destination image: towards a conceptual framework", Annals of Tourism Research, Vol. 29 No. 1, pp. 56-78.

García-Milon, A., Juaneda-Ayensa, E., Olarte-Pascual, C. and Pelegrín-Borondo, J. (2020), “Towards the smart tourism destination: key factors in information source use on the tourist shopping journey”, Tourism Management Perspectives, Vol. 36, p. 100730.

Getz, D. and Page, S.J. (2016), "Progress and prospects for event tourism research", Tourism Management, Vol. 52, pp. 593-631.

Geus, S., Richards, G. and Toepoel, V. (2016), "Conceptualisation and operationalisation of event and festival experiences: creation of an event experience scale", Scandinavian Journal of Hospitality and Tourism, Vol. 16 No. 3, pp. 274-296.

Gibson, C. and Connell, J. (2016), Music Festivals and Regional Development in Australia, Routledge, London.

Gibson, C. and Davidson, D. (2004), "Tamworth, Australia's 'country music capital': place marketing, rurality, and resident reactions", Journal of Rural Studies, Vol. 20 No. 4, pp. 387-404.

Gibson, H.J., Kaplanidou, K. and Kang, S.J. (2012), "Small-scale event sport tourism: a case study in sustainable tourism", Sport Management Review, Vol. 15 No. 2, pp. 160-170.

Gitelson, R.J. and Crompton, J.L. (1983), "The planning horizons and sources of information used by pleasure vacationers", Journal of Travel Research, Vol. 21 No. 3, pp. 2-7.

Gruen, T.W., Osmonbekov, T. and Czaplewski, A.J. (2006), "eWOM: the impact of customer-to-customer online know-how exchange on customer value and loyalty", Journal of Business Research, Vol. 59 No. 4, pp. 449-456. 
$\mathrm{IJCHM}$

33,7

Gunn, C. (1988), Vacationscapes: Designing Tourist Regions, Van Nostrand Reinhold, New York, NY.

Gursoy, D., Del Chiappa, G. and Zhang, Y. (2017), "Preferences regarding external information sources: a conjoint analysis of visitors to Sardinia, Italy", Journal of Travel and Tourism Marketing, Vol. 34 No. 6, pp. 806-820.

Gyimothy, S. (2009), "Casual observers, connoisseurs, and experimentalists: a conceptual exploration of niche festival visitors", Scandinavian Journal of Hospitality and Tourism, Vol. 9 Nos 2/3, pp. 177-205.

Hall, C.M., Scott, D. and Gossling, S. (2020), "Pandemics, transformations and tourism: be careful what you wish for”, Tourism Geographies, Vol. 22 No. 3, pp. 577-598.

Horng, J.S. and Tsai, C.T.S. (2010), "Government websites for promoting east Asian culinary tourism: a cross-national analysis”, Tourism Management, Vol. 31 No. 1, pp. 74-85.

Hosany, S. and Gilbert, D. (2010), "Measuring tourists' emotional experiences toward hedonic holiday destinations", Journal of Travel Research, Vol. 49 No. 4, pp. 513-526.

Jenkins, O.H. (1999), "Understanding and measuring tourist destination images", International Journal of Tourism Research, Vol. 1 No. 1, pp. 1-15.

Jiang, Y. and Chen, N. (2019), "Event attendance motives, host city evaluation, and behavioral intentions: an empirical study of rio 2016", International Journal of Contemporary Hospitality Management, Vol. 31 No. 8, pp. 3270-3286.

Kim, C.S., Kim, P.B., Milne, S. and O'Neill, L. (2020), "Key choice factors and preferences of attendees at academic hospitality and tourism conferences", Event Management, Vol. 24 No. 2, pp. 335-346.

Laing, J. (2018), "Festival and event tourism research: current and future perspectives", Tourism Management Perspectives, Vol. 25, pp. 165-168.

Lee, S. and Bai, B. (2016), "Influence of popular culture on special interest tourists' destination image", Tourism Management, Vol. 52, pp. 161-169.

Lew, A.A. (1987), “A framework of tourist attraction research”, Annals of Tourism Research, Vol. 14 No. 4, pp. 553-575.

Lima, E., Maia, T.S.T., Lobosco, A. and de Moraes, M.B. (2016), "Megaeventos esportivos frente a pequenos eventos: reflexões considerando-se a realidade brasileira recente", Podium Sport, Leisure and Tourism Review, Vol. 5 No. 3, pp. 89-110.

Lin, C.T. and Huang, Y.L. (2009), "Tourism competitiveness evaluation in Asian countries applying grey relational analysis and sensitivity analysis", Journal of Grey System, Vol. 21 No. 3, pp. 269-278.

Liu, H., Wu, L. and Li, X. (2019), "Social media envy: how experience sharing on social networking sites drives millennials' aspirational tourism consumption", Journal of Travel Research, Vol. 58 No. 3 , pp. 355-369.

Lu, S., Zhu, W. and Wei, J. (2020), "Assessing the impacts of tourism events on city development in China: a perspective of event system”, Current Issues in Tourism, Vol. 23 No. 12, pp. 1528-1541.

McKercher, B., Mei, W.S. and Tse, T.S. (2006), "Are short duration cultural festivals tourist attractions?”, Journal of Sustainable Tourism, Vol. 14 No. 1, pp. 55-66.

Matheson, C.M. (2008), "Music, emotion and authenticity: a study of celtic music festival consumers", Journal of Tourism and Cultural Change, Vol. 6 No. 1, pp. 57-74.

Mercille, J. (2005), "Media effects on image: the case of Tibet", Annals of Tourism Research, Vol. 32 No. 4, pp. 1039-1055.

Mossberg, L. (2007), "A marketing approach to the tourist experience”, Scandinavian Journal of Hospitality and Tourism, Vol. 7 No. 1, pp. 59-74.

Murphy, L., Moscardo, G. and Benckendorff, P. (2007), "Using brand personality to differentiate regional tourism destinations", Journal of Travel Research, Vol. 46 No. 1, pp. 5-14. 
Ok, C.M., Park, K., Park, S.B. and Jeon, H.H. (2020), "Event participation and advocacy: assessing the role of affective commitment and perceived benefits", Journal of Travel and Tourism Marketing, Vol. 37 No. 1, pp. 128-140.

Organ, K., Koenig-Lewis, N., Palmer, A. and Probert, J. (2015), "Festivals as agents for behaviour change: a study of food festival engagement and subsequent food choices", Tourism Management, Vol. 48, pp. 84-99.

Park, S.B. and Park, K. (2017), “Thematic trends in event management research”, International Journal of Contemporary Hospitality Management, Vol. 29 No. 3, pp. 848-861.

Tourist's
rational and
emotional
engagement

2389

Pickernell, D., Sullivan, D., Senyard, J. and Keast, R. (2007), "Social capital and network building for enterprise in rural areas: can festivals and special events contribute?", In 30th Institute for Small Business and Entrepreneurship Conference: International Entrepreneurship-Stimulating Smarter Successful Small Business World-wide, Perlex Associates, pp. 1-18.

Pike, S. and Ryan, C. (2004), "Destination positioning analysis through a comparison of cognitive, affective, and conative perceptions", Journal of Travel Research, Vol. 42 No. 4, pp. 333-342.

Rahman, A., Sharmin, N. and Akhter, M. (2020), "The roles of involvement, source credibility, and authenticity in the formation of online destination image", Tourism Analysis, Vol. 25 Nos 2/3, pp. 2-3.

Richards, G. (2019), "Measuring the dimensions of event experiences: applying the event experience scale to cultural events", Journal of Policy Research in Tourism, Leisure and Events, Vol. 12 No. 3, pp. $422-436$.

Ritchie, J.R.B. and Smith, B. (1991), "The impact of a mega-event on host region awareness: a longitudinal study”, Journal of Travel Research, Vol. 30 No. 1, pp. 3-10.

Russell, J.A., Ward, L.M. and Pratt, G. (1981), "Affective quality attributed to environments: a factor analytic study", Environment and Behavior, Vol. 13 No. 3, pp. 259-288.

Shamsuddin, S. and Ujang, N. (2008), "Making places: the role of attachment in creating the sense of place for traditional streets in Malaysia", Habitat International, Vol. 32 No. 3, pp. 399-409.

Stylidis, D., Shani, A. and Belhassen, Y. (2017), "Testing an integrated destination image model across residents and tourists", Tourism Management, Vol. 58, pp. 184-195.

Tarkiainen, A. and Sundqvist, S. (2009), "Product involvement in organic food consumption: does ideology meet practice?", Psychology and Marketing, Vol. 26 No. 9, pp. 844-863.

Thomas, D.C., Cuervo-Cazurra, A. and Brannen, M.Y. (2011), "From the editors: Explaining theoretical relationships in international business research: focussing on the arrows, NOT the boxes", Journal of International Business Studies, Vol. 42 No. 9, pp. 1073-1078.

Tung, V.W.S. and Ritchie, J.B. (2011), "Exploring the essence of memorable tourism experiences", Annals of Tourism Research, Vol. 38 No. 4, pp. 1367-1386.

Tyrrell, T.J. and Johnston, R.J. (2001), "A framework for assessing direct economic impacts of tourist events: distinguishing origins, destinations, and causes of expenditures", Journal of Travel Research, Vol. 40 No. 1, pp. 94-100.

Uriarte, Y.T., Antognozzi, T. and Catoni, M.L. (2019), "Investigating tourism impacts of festivals: an exploratory case study of a big-scale Comic-Con", Event Management, Vol. 23 No. 6, pp. 817-833.

Vermeir, I. and Verbeke, W. (2006), "Sustainable food consumption: exploring the consumer attitude behavioral intention gap", Journal of Agricultural and Environmental Ethics, Vol. 19 No. 2, pp. 169-194.

Vivek, S.D., Beatty, S.E. and Morgan, R.M. (2012), "Customer engagement: exploring customer relationships beyond purchase", Journal of Marketing Theory and Practice, Vol. 20 No. 2, pp. 122-146.

Wilks, L. and Quinn, B. (2016), "Linking social Capital, cultural capital and heterotopia at the folk festival", Journal of Comparative Research in Anthropology and Sociology, Vol. 7 No. 1, p. 23. 
$\mathrm{IJCHM}$

33,7

Wong, I.A., Fong, H.I.V., Leong, A.M.W. and Li, J.X. (2019), "Predicting event tourists' gambling decision: the cross-level effect of Brand equity", International Journal of Contemporary Hospitality Management, Vol. 31 No. 7, pp. 2951-2969.

Wu, G. and Liang, L. (2020), "Examining the effect of potential tourists' wine product involvement on wine tourism destination image and travel intention", Current Issues in Tourism, pp. 1-16.

Xiang, Z. and Gretzel, U. (2010), "Role of social media in online travel information search", Tourism Management, Vol. 31 No. 2, pp. 179-188.

Zeithaml, V.A., Bitner, M.J. and Gremler, D.D. (1996), Services Marketing, McGraw Hill, New York, NY.

Ziakas, V. and Getz, D. (2020), "Shaping the event portfolio management field: premises and integration", International Journal of Contemporary Hospitality Management, Vol. 32 No. 11, pp. $3523-3544$.

\section{Further reading}

Jago, L., Chalip, L., Brown, A., Mules, T. and Ali, S. (2003), "Building events into destination branding: insights from experts", Event Management, Vol. 8 No. 1, pp. 3-14.

Mair, J. and Laing, J. (2012), "The greening of music festivals: Motivations, barriers and outcomes. Applying the mair and jago model", Journal of Sustainable Tourism, Vol. 20 No. 5, pp. 683-700.

\section{About the authors}

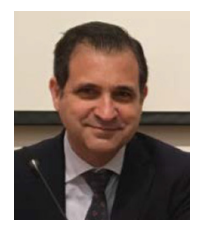

José A. Folgado-Fernández is a Professor in the Department of Financial Economics and Accounting in the University of Extremadura (UEx), Spain. Before his academic career, he worked in managing several service companies. He was given a $\mathrm{PhD}$ Extraordinary Award. His research is focussed on tourism events, branding, eTourism and destination management. He has participated as a Professor and a Lecturer in different universities in Spain, Portugal and Italy. He has published several papers in specialised journals. He is also a reviewer of international journals. He has been involved in projects for different public administrations and enterprises. ORCID iD: 000-0003-2917-0938; Researcher ID WOS: F-9582-2017. José A. Folgado-Fernández is the corresponding author and can be contacted at: jafolgado@unex.es

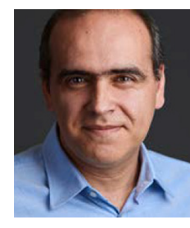

Paulo Duarte is a Professor of marketing and heads the master's degree in marketing at the University of Beira Interior. He also coordinates the Organisational Management Research Line at the Research Centre in Business Sciences (NECE). Before receiving his $\mathrm{PhD}$ in Management, he held a senior marketing position in a fast-moving consumer goods company. Academically, he has been doing research in the fields of consumer behaviour, tourism and event marketing and management and digital marketing, having published articles on these topics. He is also member of the editorial board of several international journals. ORCID iD: 0000-0001-8449-5474

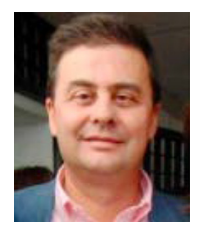

José Manuel Hernández-Mogollón is a Titular Professor in the University of Extremadura (UEx), Spain and holds a $\mathrm{PhD}$ in Business and Economic Sciences and a Master in Marketing (ESIC). He teaches Tourism Marketing in the UEx since 1998. He has participated as a Lecturer in Master and conferences in different universities in Spain, Portugal, France, Italy and Colombia. He has published a great number of works in the field of tourism management and marketing in books and Spanish and foreign high impact factor journals. He has been involved in projects for different public. ORCID iD: 0000-0002-5515-8142.

For instructions on how to order reprints of this article, please visit our website: www.emeraldgrouppublishing.com/licensing/reprints.htm Or contact us for further details: permissions@emeraldinsight.com 